\title{
POTENSI DAN STRATEGI PENGEMBANGAN PERTANIAN PERIURBAN DI KABUPATEN BOGOR
}

\section{Potencial and Strategic Development of Peri-Urban Agriculture in Bogor District}

\section{Herwita Andriamasari1)*, Wahju Qamara Mugnisjah2), dan Aris Munandar ${ }^{2)}$}

1) Pusat Pengkajian Perencanaan Wilayah, Lembaga Penelitian dan Pengabdian Masyarakat IPB, Jl. Raya Pajajaran Kampus IPB Baranangsiang, Bogor

2) Departemen Arsitektur Lanskap, Fakultas Pertanian, J1. Meranti Kampus IPB Dramaga, Bogor 16680

\begin{abstract}
There is a growing newtrend of studies internationally for analyzing the potential of food production in cities by exploring the implications for land use policies and programs, management of natural resources and changes in rural landscapes in a metropolitan area. Bogor District is one of the peri-urban areas of Jakarta Greater Area (Jabodetabek) which is directly affected by its development as one of the world's mega-city. This impact is marked by land use changes in Bogor District, where the agricultural land (both wet and dry agricultural land) has experienced significant changes within 1989 to 2013, with a total number of built-up area conversion reaching of 47,953 ha (16.04\%). This study aims to identify and analyze the potencial of peri-urban agriculture in Bogor District using remote sensing, geographycal information system and analytical hierarchy process. The main recommendations of this study is the development of multifunctional agriculture that prioritizes of environmental protection development ( eco-friendly agriculture ) with the strategy of development through economic and social aspects.
\end{abstract}

Keywords: Bogor District, Jabodetabek area, multifunction agriculture, peri-urban agriculture

\section{ABSTRAK}

Trend baru dalam pengembangan pertanian di dunia saat ini adalah menganalisis potensi produksi pangan di kota-kota besar dengan mengintegrasikan kebijakan dan program penggunaan lahan, manajemen sumber daya alam dan perubahan lanskap pedesaan di area metropolitan. Kabupaten Bogor merupakan bagian dari kesatuan wilayah mega-city Jabodetabek (Jakarta, Bogor, Depok, Tangerang, dan Bekasi) yang terkena dampak perkembangan kota secara langsung. Dampak ini ditandai dengan perubahan lahan, salah satunya pertanian (lahan basah dan lahan kering), mengalami perubahan menjadi lahan terbangun sebesar 47,953 ha (16.04\%). Studi ini bertujuan untuk mengidentifikasi dan menganalisis potensi periurban agriculuture di Kabupaten Bogor dengan menggunakan penginderaan jauh, GIS, dan AHP. Rekomendasi utama studi ini dalam pengembangan pertanian multifungsi adalah pengembangan pertanian yang mengutamakan perlindungan lingkungan (pertanian ramah lingkungan) dengan strategi pengembangan melalui aspek ekonomi dan sosial.

Kata kunci : Kabupaten Bogor, area Jabodetabek, pertanian multifungsi, pertanian peri-urban

\section{PENDAHULUAN}

Kabupaten Bogor merupakan bagian dari kesatuan wilayah mega-city Jabodetabek (Jakarta, Bogor, Depok, Tangerang, dan Bekasi). Sebagai wilayah peri-urban Jakarta, Kabupaten Bogor terpengaruh dampak (spill over) pembangunan Jakarta yang menyebabkan terjadinya perubahan penggunaan lahan. Berbagai perencanaan dan kebijakan daerah peri-urban berdampak pada pertanian, konversi lahan pertanian menjadi daerah-daerah perkotaan, serta kemungkinan mengurangi kemiskinan dan menjamin pasokan pangan (Lima, 2010).

Konversi lahan pertanian menjadi kawasan industri dan permukiman baik yang terjadi di kota maupun pinggirannya disebabkan oleh nilai lahan pertanian kalah bersaing dengan lahan-lahan yang digunakan untuk non- pertanian, seperti industri dan perumahan. Berdasarkan hasil sensus pertanian yang dilakukan BPS Provinsi Jawa Barat tahun 2013, usaha pertanian di Kabupaten Bogor dalam rentang tahun 2003-2013 mengalami penurunan 19.89\%. Menurut Fajarini (2014) lahan di Kabupaten Bogor yang paling banyak berubah dari tahun 1989 hingga 2013 adalah lahan pertanian, baik lahan pertanian basah (sawah) maupun lahan pertanian kering (kebun dan tegalan) dengan total yang berubah menjadi lahan terbangun sebesar 47,953 ha atau 16.04 persen dari total luas wilayah.

Pertanian yang dilakukan secara konvensional menyebabkan pertanian tidak difungsikan secara optimal sehingga dapat dengan mudah dikalahkan oleh sektor lain dan terkonversi. Pertanian multifungsi menjadi suatu paradigma baru yang muncul saat ini sebagai cara yang 
cocok untuk mempertahankan lahan pertanian yang tersisa dan mengembangkan pertanian tersebut. Pertanian multifungsi ini bertujuan mengintegrasikan secara spasial dan temporal penggunaan lahan dan fungsi selain untuk produksi pangan, seperti menambah nilai estetika dan rekreasi, konservasi alam, dan keseimbangan hidrologi (Renting et al., 2009).

Penelitian ini berusaha untuk memandang pertanian secara utuh dan lengkap dengan berbagai fungsinya agar dapat digunakan secara optimal pada lahan pertanian yang tersebar di Kabupaten Bogor. Oleh karena itu, penelitian ini bertujuan mengidentifikasi tipologi wilayah yang mengalami urbanisasi, menganalisis dinamika perubahan lahan pertanian di Kabupaten Bogor dan kesesuaiannya terhadap RTRW Kabupaten Bogor tahun 2005-2025, dan menganalisis potensi pengembangan pertanian perkotaan dengan penerapan multifungsi.

\section{BAHAN DAN METODE}

Penelitian dilakukan di wilayah Kabupaten Bogor dan berlangsung dari Januari 2014 hingga Januari 2015. Kabupaten Bogor terletak di Propinsi Jawa Barat, berada di antara $6^{\circ} 18^{\prime} 60 \mathrm{LS}$ dan $106^{\circ} 23^{\prime} 45-107^{\circ} 13^{\prime} 30 \mathrm{BT}$, dan terdiri dari 40 kecamatan. Lokasi penelitian dapat dilihat pada Gambar 1.

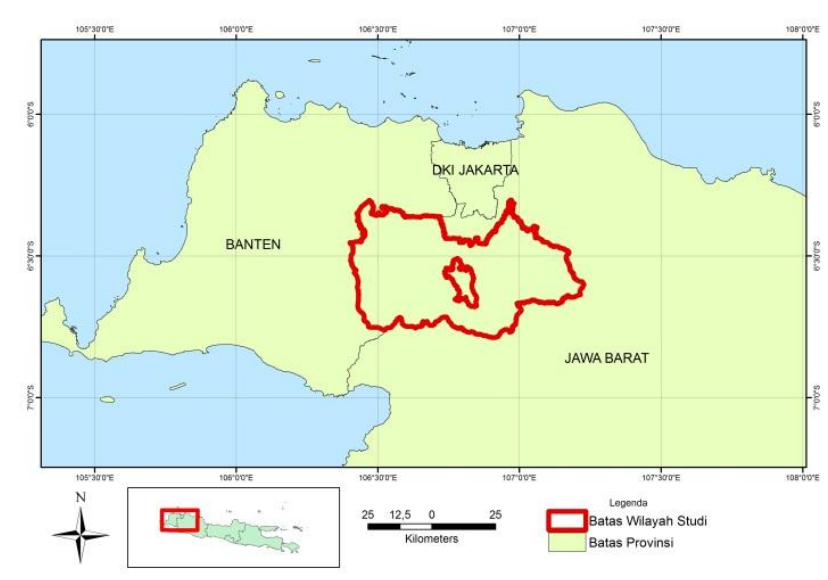

Gambar 1. Lokasi penelitian

\section{Metode Pengumpulan Data}

Pengumpulan data menggunakan metode gabungan, yaitu mengkombinasikan beberapa cara pengumpulan data primer (observasi, survei, wawancara, dan kuisioner) dan sekunder (penelusuran dokumen dan peta). Penggunaan metode pengumpulan data tersebut sesuai dengan tujuan yang akan dicapai.

\section{Analisis Data}

\section{Identifikasi Tipologi Wilayah yang Mengalami Urbanisasi}

Dalam mengidentifikasi wilayah-wilayah yang termasuk perkotaan dan perdesaan, penelitian ini menggunakan data statistik kependudukan yang dikeluarkan oleh Badan Pusat Statistik (BPS), yaitu
Kabupaten Bogor dalam Angka Tahun 2013. Data Kabupaten dalam Angka Tahun 2013 dalam bentuk tabel (dbf) digabungkan dengan peta administrasi dalam bentuk shapefile (shp) dengan proses joining data menggunakan perangkat lunak ARCGIS 9.3 dan EXCEL. Kemudian dilakukan klasifikasi mengacu pada klasifikasi yang dilakukan oleh Zasada et al. (2013) yang akan dijabarkan lebih detil pada Tabel 1.

Tabel 1. Kriteria deliniasi urban, peri-urban, dan rural

\begin{tabular}{ll}
\hline \multicolumn{1}{c}{ Sub-Wilayah } & \multicolumn{1}{c}{ Kriteria Deliniasi } \\
\hline $\begin{array}{l}\text { Urban, kepadatan tinggi } \\
\text { (U_1) }\end{array}$ & $\begin{array}{l}\text { Area dengan fungsi komersial dan } \\
\text { administratif (pusat kota), termasuk di } \\
\text { dalamnya U_2 } \\
\text { Populasi lebih dari 20,000 jiwa }\end{array}$ \\
$\begin{array}{l}\text { Urban, kepadatan rendah } \\
\text { (U-2) }\end{array}$ & $\begin{array}{l}\text { Kepadatan penduduk }>75 \text { jiwa km }{ }^{-2} \\
\text { Peri-urban, kepadatan area }\end{array}$ \\
$\begin{array}{l}\text { tinggi (PU_1) } \\
\text { Peri-urban, kepadatan area } \\
\text { rendah (PU_2) }\end{array}$ & $\begin{array}{l}\text { Kepadatan penduduk }>40 \text { jiwa } \mathrm{km}^{-2} \\
\text { dan maksimal } 300 \mathrm{~m} \text { dari area } \mathrm{rrban}^{-2}\end{array}$ \\
$\begin{array}{l}\text { Rural, kepadatan area tinggi } \\
\text { (R_1) }\end{array}$ & Kepadatan populasi $>10$ jiwa km \\
$\begin{array}{l}\text { Rural, kepadatan area } \\
\text { rendah (R_2) }\end{array}$ & Kepadatan populasi $>0$ jiwa km $\mathrm{km}^{-2}$ \\
\hline
\end{tabular}

\section{Identifikasi Dinamika Perubahan Kesesuaian Lahan Pertanian terhadap RTRW Kabupaten Bogor Tahun 2005-2025}

Identifikasi dinamika perubahan penggunaan lahan pertanian di Kabupaten Bogor tahun 1999, 2006, dan 2014 dilakukan dengan analisis spasial yang dilakukan dalam tiga tahap. Tahap pertama adalah pengunduhan citra Landsat, penggabungan kanal citra, pemotongan citra, koreksi geometri, klasifikasi terbimbing, dan pengecekan lapang. Kelas klasifikasi penggunaan lahan yang diperoleh berupa badan air, bangunan (lahan terbangun), kebun campuran, rumput/lahan kosong, semak, sawah, sawah kering, dan tegalan.

Tahap kedua adalah proses analisis dinamika perubahan penggunaan lahan pertanian. Metode yang dilakukan dalam tahap ini adalah dengan menumpangtindihkan peta penggunaan lahan semua tahun pengamatan sehingga dapat dihasilkan matriks transisi perubahan penggunaan lahan dari tahun ke tahun. Setelah proses menumpangtindihkan seluruh kelas penggunaan lahan selesai, dipilih kelas penggunaan lahan yang terkait dengan perubahan lahan pertanian (kebun, sawah, tegalan), baik pada tahun awal, tengah maupun akhir pengamatan, kemudian dibuat layout secara khusus.

Tahap ketiga adalah mengecek inkonsistensi peta RTRW Kabupaten Bogor tahun 2005-2025 dan peta klasifikasi penggunaan lahan Kabupaten Bogor tahun 2014 dengan menumpangtindihkan kedua peta tersebut.

\section{Analisis Ekonomi, Sosial, dan Ekologi}

Kondisi ekonomi, sosial, dan ekologi diketahui dengan pendekatan kualitatif melalui telaah dokumen, observasi dan wawancara informan kunci.

\section{Penyusunan Strategi Pengembangan Pertanian Multifungsi}

Hasil identifikasi dinamika perubahan lahan pertanian, penyimpangan terhadap RTRW Kabupaten Bogor tahun 2005-2025 dan identifikasi tipologi wilayah 
serta hasil observasi mengenai kondisi ekonomi, sosial, dan ekologi menjadi dasar dalam menyusun kriteria menggunakan Analytical Hierarchy Process (AHP). AHP digunakan untuk menentukan alternatif strategi sesuai dengan komponen, subkomponen dan tujuan yang ingin dicapai dalam pengembangan pertanian peri-urban di Kabupaten Bogor. Tujuan analisis ini adalah menentukan strategi pengembangan pertanian multifungsi di Kabupaten Bogor. Komponen AHP terdiri dari ekonomi, sosial, dan ekologi, kemudian dijabarkan lebih detil dalam subkomponennya. Alternatif yang ingin dikembangkan terdiri dari perlindungan terhadap lingkungan dan gaya hidup masyarakat.

Kuisioner AHP diisi oleh para pakar, antara lain adalah pakar pertanian dalam arti luas, sosial pedesaan (kelembagaan), lanskap, lingkungan, perencanaan wilayah, dan pemerintah Kabupaten Bogor (Dinas Pertanian dan Bappeda). Informasi yang telah dikumpulkan kemudian diolah dengan menggunakan perangkat lunak Expert Choice 11. Produk akhir dari penelitian ini berupa strategi pengembangan pertanian perkotaan di Kabupaten Bogor.

\section{HASIL DAN PEMBAHASAN}

\section{Tipologi Wilayah yang Mengalami Urbanisasi}

Berdasarkan Gambar 2, yang mengikuti klasifikasi yang dibuat oleh Zasada et al. (2013), Kabupaten Bogor terbagi menjadi 3 klasifikasi, yaitu Peri-urban 1 (PU_1), Peri-urban 2 (PU_2), dan Rural 1 (R_1). perdesaan dengan kepadatan penduduk tinggi. Sebanyak 5 kecamatan termasuk ke dalam klasifikasi PU_2, yaitu area peri-urban dengan kepadatan penduduk rendah dan sisanya adalah termasuk ke dalam klasifikasi PU_1, yaitu area peri-urban dengan kepadatan penduduk tinggi. Secara rinci, pengklasifikasian masing-masing kecamatan Kabupaten Bogor dapat dilihat pada Tabel 2.

Melihat fenomena yang terjadi di Kabupaten Bogor, khususnya jika dilihat dari perubahan penggunaan lahan dan kepadatan penduduk saat ini, tampak atribut "perdesaan" Kabupaten Bogor semakin menghilang. Akan tetapi atribut perkotaan masih belum muncul, yaitu rendahnya kepadatan penduduk, kurangnya aksesibilitas pada beberapa wilayah dan masih kalahnya perkembangan infrastruktur dan jasa layanan jika dibandingkan dengan kota dan kabupaten sekitarnya.

Hal ini sangat sesuai dengan konsep yang dijelaskan oleh Lardon et al. (2010), bahwa dari perpektif agronomi, peri-urbanisasi merupakan suatu proses sprawl, yaitu terjadinya re-organisasi spasial dan model pengembangan/pembangunan area pertanian, baik di dalam maupun sekitar kota, yang menciptakan konfigurasi spasial baru dan dengan disertai pembentukan pemerintahan, stakeholder dan semacamnya. Maka tipologi Kabupaten Bogor saat ini sangat tepat jika disebut sebagai wilayah periurban.

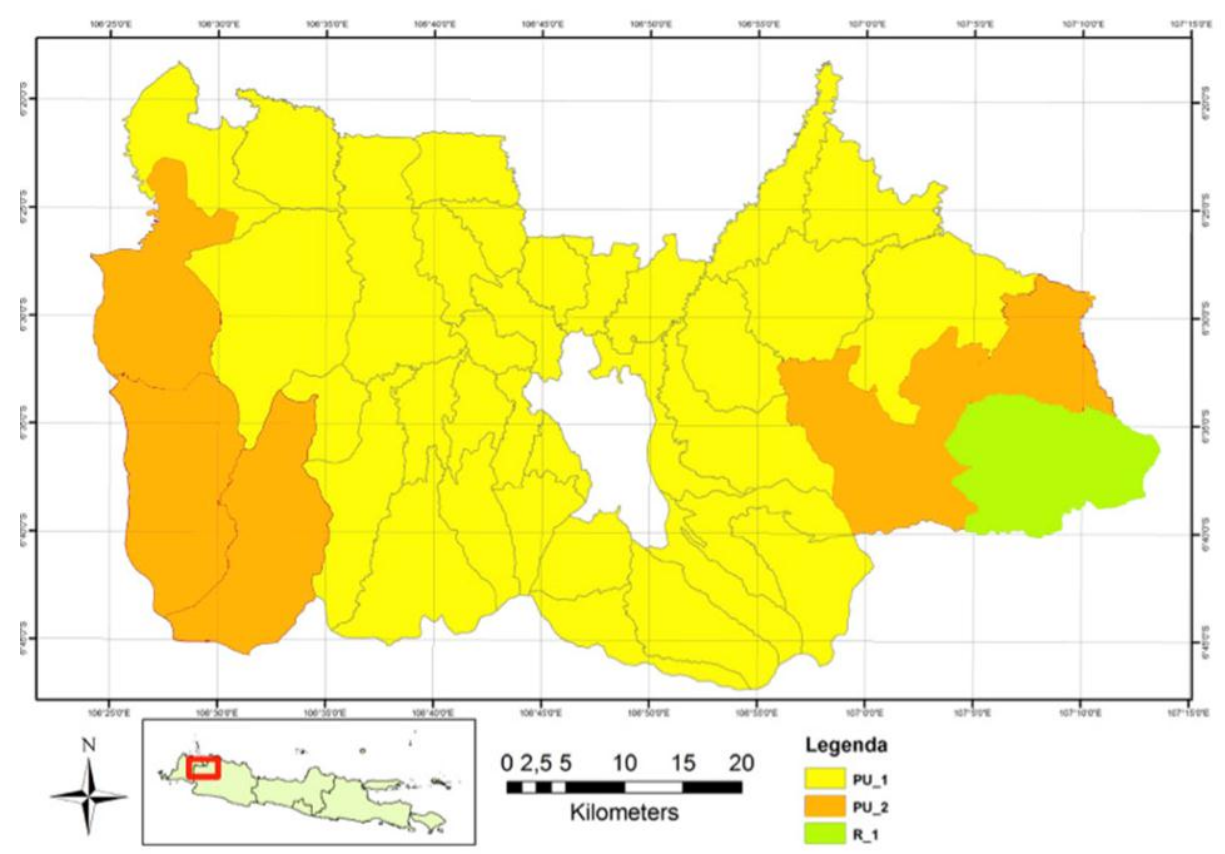

Gambar 2. Peta tipologi rural-urban di Kabupaten Bogor

Tabel 2. Tipologi per kecamatan

\begin{tabular}{cl}
\hline Tipologi Wilayah & \multicolumn{1}{c}{ Kecamatan } \\
\hline PU_1 & Babakan Madang, Bojong Gede, Caringin, Ciampea, Ciawi, Cibinong, Cibungbulang, Cigombong, \\
& Cigudeg, Cijeruk, Cileungsi, Ciomas, Cisarua, Ciseeng, Citeureup, Dramaga, Gunung Putri, \\
& Gunungsindur, Jonggol, Kelapa Nunggal, Kemang, Leuwiliang, Leuwisadeng, Mega Mendung, \\
& Pamijahan, Parung, Parungpanjang, Ranca Bungur, Rumpin, Sukaraja, Tajur Halang, Tamansari, Tenjo, \\
& dan Tenjolaya \\
PU_2 & Cariu, Jasinga, Nanggung, Sukajaya, dan Sukamakmur \\
R_1 & Tanjung Sari \\
\hline Sumber: Zasada et al. (2013)
\end{tabular}




\section{Analisis Dinamika Perubahan Lahan Pertanian dan Kesesuaiannya terhadap RTRW Kabupaten Bogor Tahun 2005-2025}

Lahan di Kabupaten Bogor dari tahun 1999 hingga 2014 mengalami perubahan yang cukup dinamis. Pada klasifikasi penggunaan lahan di Kabupaten Bogor tahun 2014, penggunaan lahan dominan pada tipe PU_1 dan PU_2 adalah kebun campuran. Klasifikasi penggunaan lahan tiga tahun pengamatan di Kabupaten Bogor disajikan pada Gambar 3, sedangkan dinamika perubahan penggunaan lahan di Kabupaten Bogor disajikan pada Gambar 4.
Pada penggunaan lahan Kabupaten Bogor tahun 1999 adalah $67.41 \%$ berupa lahan pertanian dan $32.59 \%$ berupa lahan non pertanian (badan air, lahan kosong, dan hutan). Pada tahun 2006 sebanyak $34.56 \%$ berubah menjadi lahan nonpertanian berupa lahan kosong dan lahan terbangun, dan sisanya lahan pertaniannya. Kemudian pada tahun 2014, sebanyak 51.64 \% lahan pertanian berubah menjadi lahan terbangun $(29.38 \%)$ dan lahan kosong $(22.26 \%)$, sedangkan lahan pertanian yang tidak berubah adalah sebanyak $48.36 \%$.
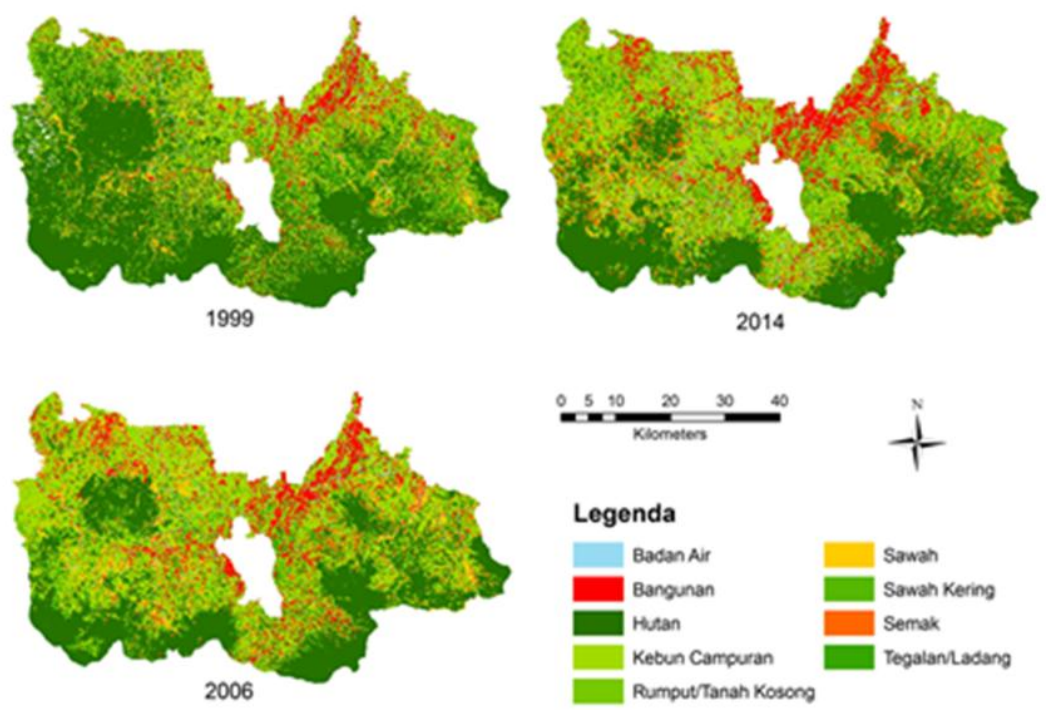

Gambar 3. Klasifikasi penutupan lahan Kabupaten Bogor tahun 1999, 2006, dan 2014

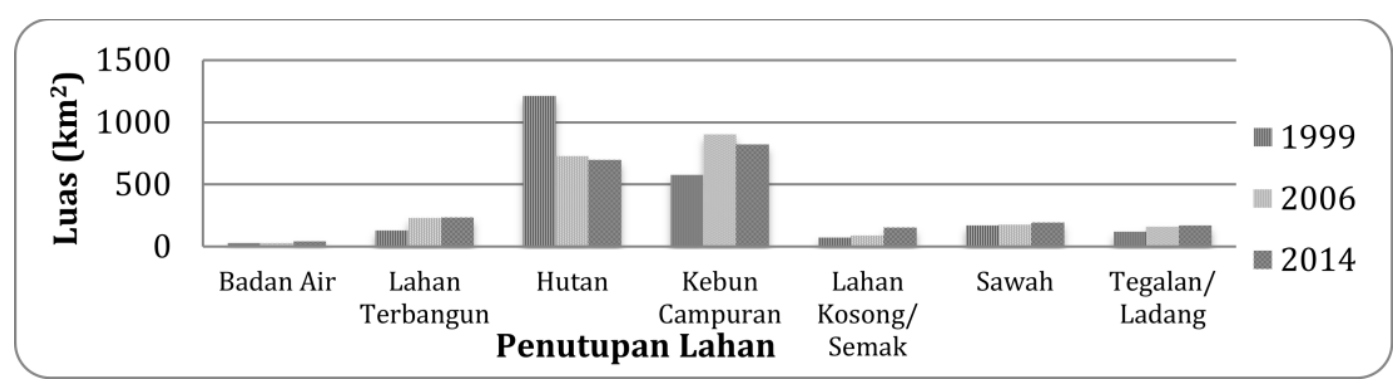

Gambar 4. Dinamika perubahan penggunaan lahan Kabupaten Bogor tahun 1999-2014

Berkurangnya lahan hutan dan badan air yang terjadi antara tahun 1999 dan 2006 disebabkan oleh peningkatan lahan terbangun, kebun campuran, sawah, dan tegalan. Rentang tahun ini merupakan rentang yang paling banyak mengalami perubahan khususnya peningkatan lahan terbangun. Hal tersebut diduga terkait dengan krisis ekonomi yang terjadi tepat setahun sebelumnya. Krisis ekonomi menyebabkan suatu fenomena banyak orang mengalami kesulitan ekonomi sehingga terjadinya penjualan properti secara besar-besaran baik dalam bentuk bangunan maupun lahan terbuka berupa sawah, kebun, tegalan, hutan bahkan lahan kosong (Ilham et al., 2005). Berdasarkan hasil analisis dinamika lahan di Kabupaten Bogor, lahan yang paling banyak terkonversi saat itu adalah hutan.
Dilihat dari Gambar 5, lahan pertanian mengalami penurunan luas dan memberikan sumbangsih kepada peningkatan luas lahan terbangun dan lahan kosong. Dinamika perubahan lahan pertanian dominan yang tersebar di Kabupaten Bogor pada masing-masing tipologi dapat dilihat pada Tabel 3 .

Tabel 3. Dinamika perubahan lahan pertanian dominan yang tersebar di Kabupaten Bogor pada masing-masing tipologi

\begin{tabular}{lccl}
\hline Tipologi & \multicolumn{2}{c}{ Tahun } \\
\cline { 2 - 4 } & 1999 & 2006 & \multicolumn{1}{c}{2014} \\
\hline PU_1 & Hutan & Kebun & $\begin{array}{l}\text { - Lahan Kosong } \\
\text { - Lahan Terbangun } \\
\end{array}$ \\
& & & - Kebun \\
\hline PU_2 & Hutan & Sawah & Sawah \\
\hline R_1 & Hutan & Hutan & Sawah \\
\hline
\end{tabular}


Inkonsistensi antara alokasi ruang RTRW Kabupaten Bogor 2005-2025 dengan hasil penggunaan lahan pertanian Kabupaten Bogor tahun 2014 rata-rata 15\%-30\% (Tabel 4). Hal ini berarti hingga saat ini masih ada lahan pertanian yang tidak/belum difungsikan secara optimal menjadi lahan pertanian sesuai dengan RTRW 2005-2025. Inkonsistensi yang ada saat ini salah satunya meliputi alokasi yang aktualnya digunakan sebagai lahan terbangun sebesar $26.81 \%$, dimana sangat sulit mengubah lahan terbangun menjadi lahan pertanian. Alokasi ruang aktual lainnya berupa badan air, hutan, dan lahan kosong dapat diusahakan untuk dijadikan lahan pertanian di masa yang akan datang. diprioritaskan untuk pengembangan pertanian multifungsi di Kabupaten Bogor adalah perlindungan lingkungan.

Berdasarkan hasil AHP, alternatif utama pengembangan pertanian multifungsi adalah pengembangan pertanian yang mengutamakan perlindungan lingkungan, artinya aktivitas pertanian yang dipilih harus sedikit mungkin menggunakan bahan kimia, memperhatikan ekosistem lingkungan, dan menjaga sumber daya alam. Pertanian ramah lingkungan dapat diimplementasikan dengan beberapa sistem, yang sudah dan sedang dilakukan adalah pertanian organik, sistem pertanian terpadu, sistem pertanian masukan luar rendah, dan sistem lain yang dikembangkan dengan mengacu pada kaidah dan tujuan yang ingin dicapai.

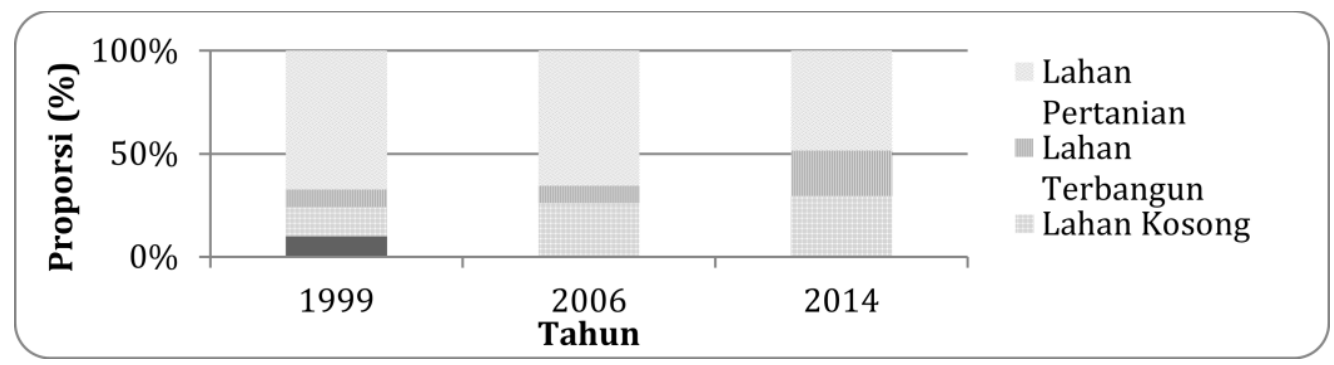

Gambar 5. Persentase dinamika perubahan lahan pertanian tahun 1999, 2006, dan 2014

Tabel 4. Evaluasi inkonsistensi RTRW Kabupaten Bogor 2005-2025 dengan penggunaan lahan pertanian Kabupaten Bogor tahun 2014

\begin{tabular}{cccccc}
\hline \multirow{2}{*}{ Pola Ruang RTRW Kabupaten Bogor 2005- } & \multicolumn{5}{c}{ Penggunaan Lahan Pertanian Kabupaten Bogor Tahun 2014 (\%) } \\
\cline { 2 - 6 } 2025 & $\begin{array}{c}\text { Badan } \\
\text { Air }\end{array}$ & Hutan & $\begin{array}{c}\text { Lahan } \\
\text { Kosong }\end{array}$ & $\begin{array}{c}\text { Lahan } \\
\text { Terbangun }\end{array}$ & Total \\
\hline Kawasan Perkebunan & 0.71 & 1.42 & 0.71 & 0.71 & 3.54 \\
Kawasan Pertanian Lahan Basah & 10.05 & 8.62 & 12.92 & 11.49 & 43.08 \\
Kawasan Pertanian Lahan Kering & 4.23 & 8.46 & 6.77 & 5.92 & 25.38 \\
Kawasan Tanaman Tahunan & 2.90 & 8.69 & 7.72 & 8.69 & 28.00 \\
Total & 17.89 & 27.18 & 28.12 & 26.81 & 100.00 \\
\hline
\end{tabular}

\section{Analisis Ekonomi, Sosial, dan Ekologi}

Pengembangan ekonomi di Kabupaten Bogor diarahkan ke arah agroindustri pertanian (skala menengah besar dan menengah kecil). Dimana agroindustri ini menyumbangkan nilai tertinggi pada PDRB atas dasar harga berlaku di Kabupaten Bogor pada tahun 2012. Berdasarkan hal tersebut pada aspek ekonomi, pertanian dapat berperan dalam penyediaan lapangan kerja dan penyediaan pangan itu sendiri.

Pada aspek sosial, pertanian di Kabupaten Bogor dapat berperan dalam perkembangan pendidikan, wisata, budaya dan organisasi antar petani. Sedangkan pada aspek ekologi, sesuai dengan fungsi pertanian bagi lingkungan, maka pertanian dapat menjadi daerah perlindungan aliran sungai dan sumber daya air, mencegah erosi, menjadi tempat pengelolaan sampah organik, berkontribusi dalam perbaikan iklim mikro dan sebagai habitat flora dan fauna.

\section{Strategi Pengembangan Pertanian Multifungsi}

Hasil analytical hierarchy prosses (AHP) dapat dilihat pada Gambar 6, dimana kedua komponen (ekonomi dan sosial) memiliki tingkat prioritas yang relatif sama, dengan komponen ekonomi sedikit lebih tinggi jika dibandingkan dengan komponen sosial. Alternatif yang

\section{Inkonsistensi: 0.06}
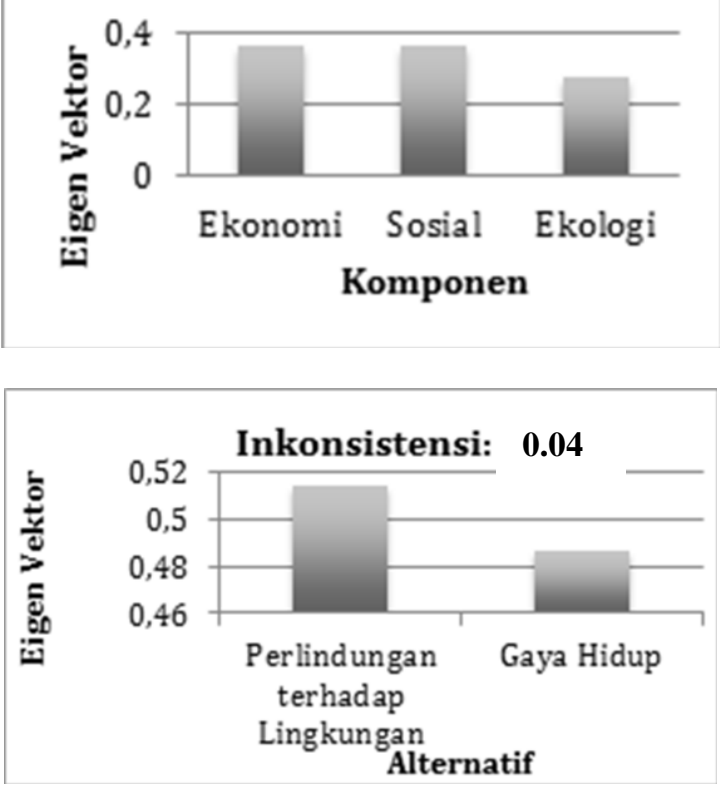

Gambar 6. Komponen dan alternatif strategi pengembangan pertanian multifungsi di Kabupaten Bogor 
Alternatif tersebut kemudian dikembangkan secara strategis melalui aspek ekonomi dan sosial. Berdasarkan aspek ekonomi, pengembangan pertanian multifungsi di Kabupaten Bogor adalah dengan transformasi aktivitas pertanian sebagai alternatif penyedia lapangan kerja secara formal. Selain itu, sebagai penyedia pangan di lingkungan kota, pertanian di Kabupaten Bogor memiliki harga yang lebih murah karena adanya reduksi dalam biaya, yaitu biaya transportasi dan pengelolaan (Indraprahasta dan Agustina, 2012). Pengembangan pertanian secara strategis melalui aspek sosial dilakukan dengan pemantapan pertanian sebagai salah satu identitas lanskap budaya perkotaan di Indonesia, penguatan pendidikan petani dan penyuluh serta dengan dukungan litbang dalam pengembangan pertanian dan penguatan organisasi petani.

\section{SIMPULAN}

Kabupaten Bogor termasuk tipologi wilayah periurban, dimana 34 kecamatan termasuk ke tipologi PU_1 yang artinya wilayah peri-urban dengan kepadatan area tinggi, sedangkan 5 kecamatan termasuk tipologi PU_2 dengan kepadatan area rendah. Dinamika perubahan lahan pertanian dominan yang tersebar di Kabupaten Bogor tipe PU_1 yang pada awalnya (tahun 1999) berupa hutan kemudian berubah menjadi lahan pertanian kebun pada tahun 2006, lalu pada tahun 2014 sebagian berubah menjadi lahan kosong dan lahan terbangun, sebagian lagi tetap menjadi lahan pertanian kebun. Ketidaksesuaian penggunaan lahan pertanian aktual tahun 2014 dengan RTRW 2005-2025 adalah rata-rata < 30 persen, diantaranya berupa badan air, lahan terbangun, lahan kosong, dan hutan. Rekomendasi utama pengembangan pertanian multifungsi adalah pengembangan pertanian yang mengutamakan perlindungan lingkungan (pertanian ramah lingkungan) dengan strategi pengembangan melalui aspek ekonomi dan sosial.

\section{DAFTAR PUSTAKA}

[BPS] Badan Pusat Statistik. 2014. Kabupaten Bogor dalam Angka Tahun 2013. Badan Pusat Statistik Kabupaten Bogor, Jakarta.
Fajarini, R. 2014. Dinamika perubahan lahan dan perencanaan tata ruang di Kabupaten Bogor [Tesis]. IPB. Bogor.

Ilham, N.Y., Syaukat, dan S. Friyanto. 2005. Perkembangan dan faktor-faktor yang mempengaruhi konversi lahan sawah serta dampak ekonominya. SOCA, 5: 203-212.

Indraprahasta, G.S., dan I. Agustina. 2012. Urban agriculture Activity and its potentials to eradicate urban poverty in Jakarta. Jurnal Tata Loka, (14) 3: 186-200.

Lardon, S., M. Galli, E. Marraccini, and E. Bonari. 2010. Peri-urbanisation and Peri-urban Agriculture: Issues and Proposals. In M. Galli, S. Lardon, E. Marraccini, and E. Bonari (Eds.). Agricultural Mangement In Peri-Urban Areas: The Experience Of International Workshop. Felicie Editore Srl., Land Lab - Scuola Superiore Sant'Anna.

Lima, P.T., A.C. Munoz, G.A. Jimenez, and S.C. Prado. 2010. Urban agriculture as a part of a sustainable metropolitan development program: A case study in Mexico City. The Journal of Field Action: Field Action Science Reports. Special Issue 1| 2010.

Renting, H., W.A.H. Rossing, J.C.J. Groot, J.D. Van der Ploeg, C. Laurent, D. Perraud, D.J. Stobbelaar, M.K. Van Ittersum. 2009. Exploring multifunctional Agriculture. A review of conceptual approaches and prospects for an integrative transitional framework. Journal of Environmental Management, $90: 112-123$.

[UNDESA] United Nation Departement of Economic and Social Affairs. 2008. World Urbanization Prospects: The 2007 Revision. United Nation Departement of Economic and Social Affairs, New York.

Zasada, I., W. Loibl, M. Kostl, and A. Piorr. 2013. Agriculture under human influence: a spatial analysis of farming system and land uses in European rural-urban-region. European Countryside, 5: 71-88. 